
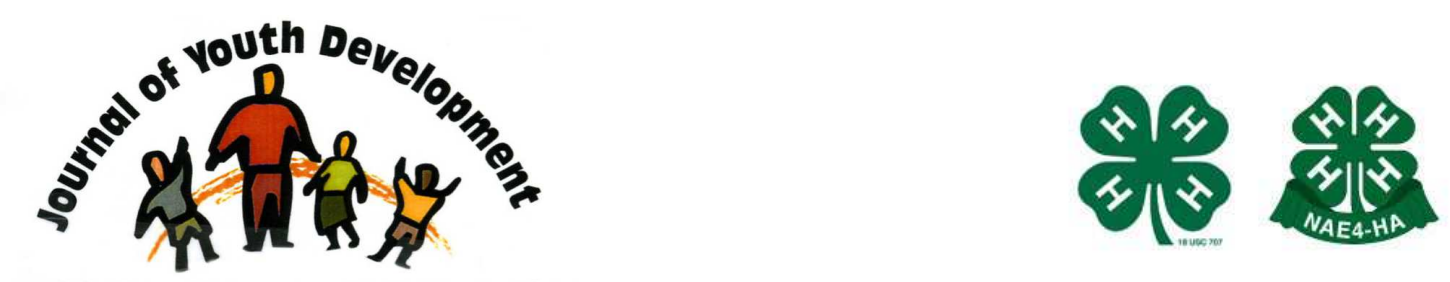

Bridging Research \& Practice

\title{
Utilizing 4-H in Afterschool Settings: Two Approaches for Integration
}

\author{
Rachel Rudd \\ Utah State University \\ Farmington, UT \\ rachel.rudd@usu.edu \\ Naomi Brower \\ Utah State University \\ Ogden, UT \\ naomi.brower@usu.edu
}




\title{
JOURNAL OF YOUTH DEVELOPMENT \\ bridging research and practice

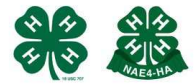

\section{Utilizing 4-H in Afterschool Settings: Two Approaches for Integration}

\author{
Rachel Rudd and Naomi Brower \\ Utah State University
}

\begin{abstract}
As our communities grow and change, afterschool programs represent an avenue to bring resources to populations which would otherwise not be available to them. Combining 4-H with the afterschool environment can be beneficial in supporting and raising the quality of afterschool programs being offered. This article explores the benefits and challenges of two approaches of implementing 4-H programming in afterschool settings: the 4- $\mathrm{H}$ managed program that is created and run solely by $4-\mathrm{H}$ faculty and staff and the 4-H afterschool partnerships which are facilitated in partnership with existing afterschool programs. Regardless of the approach, combining 4- $\mathrm{H}$ with afterschool programs can strengthen well established programs and can enhance the quality of all afterschool programs.
\end{abstract}

\section{Utilizing 4-H in Afterschool Settings: Two Approaches For Integration}

The hours between school and when parents get home from work have been proven to be a critical time for youth and families (Afterschool Alliance, n.d.; Miller, 2003). While it is true that afterschool programs provide a safe haven for youth if their parents are unavailable (Afterschool Alliance, n.d.; Newman, Fox, Flynn, \& Christeson, 2000), we also see an increasing need for supplemental education as the United States falls behind in different areas of education (Miller, 2003). As educators are continually stretched to capacity, the need arises for education to be rounded out through other avenues. Afterschool programs can effectively fill in the cracks that seem to get larger every year (Afterschool Alliance, n.d; Miller, 2003). As afterschool programs become increasingly important to the development of our youth, it is important to ensure these programs are structured and implemented in a high quality way.

4-H is an ideal partner for afterschool programs because of the high quality projects, goals, and ideologies of 4-H. The 4-H organization was established in 1902 and has years of longitudinal research to support the positive youth development benefits of 4- $\mathrm{H}$ programming (Lerner, Lerner \& Colleagues, 2011). The mission of 4-H is to assist youth in acquiring knowledge, 
building character, and developing life skills in a fun learning environment that will enable them to become self-directing, productive members of society (National 4-H Council, n.d.). 4-H has a "learning by doing" ideology to "make the best better" (National 4-H Council, n.d.).

While youth can choose to participate in a vast array of project areas that fit their interests, the current mission mandates of 4-H include healthy living, science, and citizenship (National 4-H Headquarters, n.d). These mission mandates align with the research and programming efforts of USDA, and the National Institute of Food and Agriculture. They are also aimed at helping prepare the next generation of scientists, engineers and technology experts who will keep the United States competitive with other countries around the world.

The 4-H program has its roots in an agriculture background that often appeals more to rural youth; however, 4-H has strong membership in both rural and urban environments because of the breadth of curriculum and utilization of more nontraditional formats that are effective in metropolitan areas such as afterschool programs (Cano \& Bankston, 1993; Fehlis, 1992; Van Horn, Flanagan, \& Thomson, 1999). Providing 4-H programming in nontraditional formats extends the program to more youth that may not otherwise be able to participate in 4- $\mathrm{H}$ programs, especially in urban areas (Fehlis, 1992; Halpurn, 2002).

\section{Integrating 4-H into Afterschool Settings}

Several afterschool programs in Utah have found great success in implementing 4-H programming into afterschool settings. The purpose of this article is to highlight the value of integrating 4-H programming into afterschool settings and provide an overview and suggestions of how this can be done.

Youth who attend afterschool programs generally meet at the school or another easily accessible location soon after school is over. Youth are then involved in programming, which usually includes homework tutoring, clubs, and group games that involve both fine and gross motor skills, and other enrichment activities until about 5:30 p.m. Because this common schedule is utilized by both afterschool programs with and without current 4-H involvement, integrating 4- $\mathrm{H}$ programs into an afterschool program is an easy addition to any program. The 4-H curriculum fits best into the club/enrichment time; however, other group times, such as announcements when the youth first arrive or snack time, is also a great timeframe for integrating elements of $4-\mathrm{H}$ programming.

Furthermore, the 4-H model shares and supports the same youth development components that most afterschool programs strive to adopt, such as the 40 developmental assets model (Scales, Benson, Leffert, \& Blyth, 2000), healthy living, and service. 4-H curriculum and resources can be a great asset to afterschool staff to enrich and expand their club offerings and encourage opportunities for youth to develop leadership skills.

In addition, many of the 4-H curricula support youth in learning preventative life skills such as: career exploration, healthy body/lifestyles, financial literacy, healthy interpersonal relationships, prevention of tobacco/drug/alcohol abuse, prevention of violence/gang affiliation, and pregnancy/sexually transmitted infection (STI) prevention, which are often required as national mandates for afterschool programs and grant monies (Department of Workforce Services, 2011). 


\section{Two Approaches for Integration}

In Utah, there are two main ways that 4- $\mathrm{H}$ has been utilized in afterschool settings. The two approaches include a total 4-H managed program and a 4-H partnership. Each approach has benefits and challenges, which will be shared below.

\section{4-H Managed Programs}

A 4-H managed afterschool program is an afterschool program created and run solely by 4-H staff. This approach may be best utilized by those who want to start an afterschool program in an area where currently there are not afterschool programs serving a population. Funding for this program is generally acquired in coordination with the 4- $\mathrm{H}$ faculty in the county where the program will be held. In Utah, programs of this nature sustain themselves through grant monies often related to federal, state, private, or 4-H funds, both national and local, along with parent fees. Once funding is obtained, the 4-H faculty generally oversees staff training, budget management, and implementation of the afterschool programs.

Implementing the 4-H program in this way provides freedom to structure the program to highlight all important aspects of the 4-H program, such as leadership opportunities, creating a sense of belongingness, opportunities for service, and experiencing a solid club environment where youth complete projects based on 4-H curriculum in a hands-on learning environment. It also promotes $4-\mathrm{H}$ attendance at other $4-\mathrm{H}$ events such as summer camps, county and state fairs, and county and state contests where youth have an opportunity to showcase the skills they have learned in their 4-H activities. Because the program is implemented with money acquired by $4-\mathrm{H}$ and is managed completely by $4-\mathrm{H}$ trained staff, the youth involved have a solid connection to the 4-H program and its ideology. 4-H volunteers are also likely to be utilized along with paid staff to supplement enrichment activities. This connection directly to 4-H provides high quality programming and activities utilizing curriculum that has been peer reviewed and offered by a land grant university.

While this approach to 4-H afterschool management has many benefits, the total 4-H managed program requires much time and effort from $4-\mathrm{H}$ county faculty to ensure the program will have the funding, training, and resources necessary to ensure a successful program. This may be a challenge in some areas since not every county may have the staffing resources that can provide the amount of time necessary to create and sustain an afterschool program. Funding is often competitive and can be challenging to obtain.

In addition, because this approach is essentially starting a new afterschool program from scratch, there are many community partners and resources that need to be secured in order to ensure program success. Some of these include support from the local school district, school principals and staff, and partnership for space if it is shared either with a school or another entity.

\section{4-H Afterschool Partnerships}

Another approach of 4-H implementation in an afterschool setting is creating partnerships with the school district and any other entities already offering afterschool programs. In this approach the funding, implementation, and management of facilities and staff is provided by programs that are school-based, government/recreation based, community based, or private providers. These partnering agencies offer the staff training and resources to run the afterschool program on an everyday basis, and 4-H faculty and staff offer training and resources specifically to implement 4-H curriculum and programming into the afterschool setting. 
For example, the 4-H faculty may provide training to afterschool staff throughout the year on some of the more complicated 4-H curriculum, such as robotics, rocketry, or cake decorating; and the afterschool staff then implement the curriculum for an agreed upon minimum level of time (i.e., one hour per week or one 4-H club per school block). Alternately, sites may also choose to implement this type of partnership through coordinating 4- $\mathrm{H}$ volunteers to go into the programs and teach the youth directly, with afterschool staff serving as a supportive role in the 4-H clubs.

In addition to training, local 4-H offices may also provide resources from a lending library, which includes curriculum and supplies for 4-H activities (e.g., rocket launchers, GPS units, kits, etc.). The afterschool staff can borrow and utilize kits from the lending library in order to facilitate 4-H clubs in the afterschool program. When resources contain consumable supplies, a small stipend fee may be charged in order to replenish the supplies.

Implementing 4-H programming into existing afterschool programs can be a benefit to afterschool staff, 4-H faculty and staff, and youth attending the programs. Afterschool staff can receive more curriculum and resources to provide better quality programming for their youth. In addition, 4-H faculty and staff can reach more youth within communities who may not otherwise be involved in 4-H programming. Most importantly, this partnership will provide youth with more opportunities at the school and in the community to develop leadership, skills in different project areas, and receive recognition for their efforts.

While 4-H partnerships are an effective way to enhance already existing afterschool programs, one of the challenges of implementing 4- $\mathrm{H}$ in this way is that each site chooses to implement their programs differently and do not always include all essential elements of $4-\mathrm{H}$, which ensures the effectiveness of the program. In addition, much of the success of this partnership rests in the afterschool staff's interest level and dedication of consistently implementing 4-H programming that is available to them. For example, afterschool staff may utilize 4-H curriculum without letting youth know they are connected in any way to 4-H. In this case, the youth would obviously be less likely to feel a sense of connection to 4-H or attend any 4-H activities outside of the school.

On the other hand, staff who fully implement the 4-H program can provide opportunities for youth to feel connected to the program not only at the school but within the county. Strong partnerships with the 4-H faculty and staff could allow for unique 4-H opportunities to be developed at the school according to the needs of the youth. Much of the limitation of this approach lies within the delicate balance of the partnership between the 4-H county office and the afterschool sites, and especially the willingness of the faculty and staff on both sides to implement the 4-H program in a way that will be most beneficial for the youth.

\section{Successful Implementation}

One of the challenges with all afterschool programs is the ability to measure the quality and success of the program. According to the Utah Afterschool Network (UAN), the statewide professional organization for afterschool programs, "Program quality is an ongoing process involving reflection and thoughtful assessment and is best accomplished through continuous practice that includes staff, parents, youth, and community partners" (UAN, 2011, para. 1). In an effort to support afterschool providers in their assessment efforts, the UAN utilized a statewide task force to develop a tool for assessing quality in programs. 
The tool was developed by incorporating ideas from other proven quality assessment tools such as the NAA (National Afterschool Association) Standards for Quality School Age Care, School Age Environment Rating Scale, and writing new indicators tailored to the specific needs of the state. As found in the "Learn New Skills" area of the assessment tool, quality programs include "interactive, project-based activities that encourage critical thinking and self-expression" (UAN, 2011, para. 6).

The assessment tool also has indicators to measure cognitive development, creativity, selfexploration and development, leadership, team work, social skills, self-responsibility, and service opportunities. These indicators for high quality programs are directly in line with what 4-H offers in curriculum and activities to improve these skills for youth of this age group.

All afterschool sites in Utah that have utilized the 4-H implementation approaches outlined above have scored very high on this assessment tool for quality. Based on this, it is anticipated that incorporating 4-H into afterschool programs can help to improve scores in similar areas of measurement using comparable quality assessment tools. For example, a study completed by Bunnell and Pate (2006), found that $99 \%$ of parents $(\mathrm{N}=287)$ either agreed or strongly agreed that the "4-H afterschool club is a place where their child learns new skills and interests" ( $p$. 78). The same study also found that $94 \%$ of youth $(\mathrm{N}=506)$ stated they learned new skills and $93 \%$ felt that they developed more confidence about themselves in addition to many other positive outcomes (Bunnell \& Pate, 2006).

\section{Conclusion}

As our communities grow and change, afterschool programs represent an avenue to bring resources to populations, which would otherwise not be available to them. These afterschool programs can not only provide a safe environment for youth to spend their afterschool hours, but can also provide them with positive and constructive learning opportunities and help fill the gaps of other educational programs. Continually striving to improve and provide quality programming in afterschool programs is essential in order to ensure the best outcomes for youth and make sure the program does not have the reputation of "flying by the seat of their pants" or simply being seen as a daycare facility.

Combining 4-H with the afterschool environment can be beneficial in raising the quality of afterschool programs being offered. 4-H faculty and staff provide expertise in youth development that can help others to develop new afterschool sites, strengthen well established programs and enhance the quality of all afterschool programs across the nation (Bunnell \& Pate 2006). 4-H, with its ideology, goals, and tried and true practices, is an excellent way for afterschool programs to improve quality and ensure the youth are participating in a program that best meets their needs.

\section{References}

Afterschool Alliance. (n.d.). Retrieved from http://www.afterschoolalliance.org

Bunnell, J., Pate, R. (2006). 4-H afterschool: Making an impact. Journal of Youth Development, 1 (1). Online: http://data.memberclicks.com/site/nae4a/JYD 060101final.pdf 
Cano, J., Bankston, J. (1993). Involving minority youth in 4-H. Journal of Extension, 31(1). Article 1RIB4. Available at: http://www.joe.org/joe/1993spring/rb4.php

Department of Workforce Services, Office of Work and Family Life. (2011). Safe Passages III, Request for Proposal. Department of Workforce Services, Salt Lake City, UT.

Fehlis, C.P. (1992). Urban extension programs. Journal of Extension, 30 (2). Article 2FEA3. Available at: http://www.joe.org/joe/1992summer/a3.php

Halpern, R. (2002). A different kind of child development institution: The history of afterschool programs for low-income children. Teachers College Record, Vol. 104, No. 2, p. 178-211.

Lerner, R.M., Lerner, J.V., \& Colleagues. (2011). Waves of the future 2009: Report of the findings of the first six years of the $4-\mathrm{H}$ study of positive youth development. Chevy Chase, MD.

National 4-H Council. (n.d.). http://www.4-

h.org/uploadedFiles/About Folder/Research/Tufts Data/4-H-Positive-Youth-DevelopmentStudy-Wave-6.pdf

Miller, B.M. (2003). Critical hours: Afterschool programs and educational success. Brookline, MA: Nellie May Education Foundation. http://www.nmefdn.org/uploads/Critical Hours.pdf

National 4-H Council. (n.d.). Retrieved from http://www.4-h.org

National 4-H Headquarters. (n.d.). Retrieved from http://www.national4-hheadquarters.gov/

Newman, S.A., Fox, J.A., Flynn, E.A., \& Christeson, W. (2000). America's after-school choice: The prime time for juvenile crime, or youth enrichment and achievement. Fight Crime, Invest in Kids, Washington, D.C. http://www.eric.ed.gov/PDFS/ED445823.pdf

Scales, P.C., Benson, P.L., Leffert, N., \& Blyth, D.A. (2000). Contribution of developmental assets to the prediction of thriving among adolescents. Applied Developmental Science, $4(1)$, 27-46.

Utah Afterschool Network (2011). Quality. Retrieved from http://utahafterschool.org/quality

Van Horn, B.E., Flanagan, C.A., Thomson, J.S. (1999). Changes and challenges in 4-H (part 2). Journal of Extension 37 (1). Article 1COM1. Available at:

http://www.joe.org/joe/1999february/comm1.php

(c) Copyright of Journal of Youth Development Bridging Research and Practice. Content may not be copied or emailed to multiple sites or posted to a listserv without copyright holder's express written permission. However, users may print, download or email articles for individual use. 